Determining Pomegranate Water and Nitrogen Requirements with Drip Irrigation

2 James E. Ayars ${ }^{1 *}$, Claude J. Phene ${ }^{2}$, Rebecca C. Phene ${ }^{3}$, Suduan Gao ${ }^{1}$, Dong Wang ${ }^{1}$, Kevin R.

3 Day $^{4}$, Donald J. Makus ${ }^{5}$

$4{ }^{1}$ USDA, Agricultural Research Service, San Joaquin Valley Agricultural Sciences Center, 9611

5 South Riverbend Ave., Parlier, CA 93648-9757 USA

$6 \quad{ }^{2}$ SDI+, PO Box 314, Clovis, CA 93613 USA

$7 \quad{ }^{3}$ University of California, Kearney Agricultural Research and Extension Center, 9240 S.

8 Riverbend Ave. Parlier, CA 93648 USA

$9{ }^{4}$ County Director, Kings and Tulare Counties, University of California, Cooperative Extension, 104437 B S. Laspina, St., Tulare, CA 93274-9537

$11{ }^{5}$ USDA, Agricultural Research Service, San Joaquin Valley Agricultural Sciences Center, 9611

12 South Riverbend Ave., Parlier, CA 93619 USA, Deceased.

\title{
14 ABSTRACT
}

15 Despite being an ancient crop there is limited knowledge on the water and nitrogen (N)

16 requirements of pomegranate. We conducted research at the University of California, Kearney

17 Agricultural Research and Extension Center (KARE) to determine the water and $\mathrm{N}$ requirements

18 of a developing pomegranate orchard. Pomegranate trees (Punica granatum L. var. Wonderful)

19 were planted in 2010. The irrigation treatments were surface drip irrigation (DI) and subsurface

20 drip irrigation (SDI) with three

$21 \mathrm{~N}$ sub-treatments ( $\mathrm{N}$ application rates of 50, 100, and $150 \%$ of current practice) and 5

22 replications in split-plot design. A weighing lysimeter located in the experimental field was used to automatically irrigate the orchard after $1.0 \mathrm{~mm}$ of measured crop water use. The trees received uniform application of fertilizers and water during the first two years of growth to insure uniform stand establishment prior to beginning the experiment. The $\mathrm{pH}$ of the irrigation water was maintained at $6.5+/-0.5$ by injection of $\mathrm{N}$ as urea sulfuric acid (US-10; $10 \% \mathrm{~N}$ ). Differential $\mathrm{N}$ treatments were started in 2012 and continued through the end of the project. Phosphorus $\left(\mathrm{PO}_{4}{ }^{-}\right.$ $\mathrm{P})$ was continuously injected during irrigation and potassium $\left(\mathrm{K}_{2} \mathrm{~T}\right)$ was injected weekly. We report the results of the study from 2013 to 2015. From 2013 to 2015 the applied $\mathrm{N}$ ranged from 62 to $332 \mathrm{~kg} / \mathrm{ha}$ and the total yields ranged from 33,144 to $57,769 \mathrm{~kg} / \mathrm{ha}$. There were no

31 statistical differences in yield within any year related to total applied N. The yearly applied

32 irrigation water increased as the plant size increased. The total water requirement is

33 approximately $952 \mathrm{~mm}$ and the maximum daily water use was $10.5 \mathrm{~mm}$. The DI irrigation

34 application went from $645 \mathrm{~mm}$ to $932 \mathrm{~mm}$ and the SDI application increased from $584 \mathrm{~mm}$ to

\footnotetext{
* Corresponding Author,

Email addresses - james.ayars@ars.usda.gov, claudejphene@gmail.com, rcphene@ucanr.edu, suduan.gao@ars.usda.gov, dong.wang@ars.usda.gov, krday@ucdavis.edu
} 
$843 \mathrm{~mm}$ from 2013 to 2015 . A fifth order polynomial was fitted to the crop coefficient using the 2015 data. The use of SDI resulted in lower weed pressure in the SDI plots than in the DI irrigated plots in all three years. High frequency irrigation resulted in nitrate being managed within the soil profile to a depth of $1.5 \mathrm{~m}$ by minimizing deep percolation losses to the groundwater. While the yields were higher in the SDI than the DI system they were not statistically different. Although there were some differences in $\mathrm{N}$ content in tree leaves and fruit peels, there were no differences in fruit arils among $\mathrm{N}$ rates. The $\mathrm{N}$ requirement is in the range of 62 to $112 \mathrm{~kg} / \mathrm{ha}(109-198 \mathrm{~g} /$ tree $)$ for a mature pomegranate orchard and will ultimately depend on the planting density.

\section{1. Introduction}

Pomegranate has been cultivated throughout the Mediterranean region continuously from 3000 BCE (Stover and Mercure, 2007). It is widely considered that pomegranate was native to northern India and areas of Iran and from those origins spread throughout the world reaching China by 100 BCE. In the 1500's and 1600's it was introduced in Central and South America and in the early 1700's in Florida and Georgia in the United States. By 1770 it had made its way to the west coast of the United States and was being grown in the Franciscan missions in California. Pomegranate is ideally suited to a Mediterranean climate with a warm summer and a mild winter which describes the climatic conditions found in the San Joaquin Valley of California, the principal production area in the United States. There are approximately 12,145 ha under production in California compared to 108,000 ha in India, 71,000 ha in China, 65,000 ha in Iran, 27,000 ha in Turkey, and 6,000 ha in Spain (Stover and Mercure, 2007).

One of the drivers of the interest in pomegranate in the United States was the recent demand for juices with healthy bioactive compounds, mineral nutrients, and high antioxidant content (Basu and Penugonda, 2008). The medicinal qualities of pomegranate were recognized 1000's of years ago, with extracts of the tannin rich roots being used to rid people of tapeworms. Pomegranate extractions were also used as plasters to reduce eye and skin inflammation and to aid in digestion. There is an extensive literature on uses of pomegranate in medicine that include: treating diabetes, leprosy, to halting diarrhea, and hemorrhage. Various parts of the tree (leaves, bark, and roots) as well as the fruit are used for medicinal purposes. Some of the medicinal uses

65 Galindo, et al. 2014; Li, et al. 2015).

66 Despite this long history of use throughout the world there is limited literature that has quantified the basic agronomic requirements (fertilizer, water) for production of pomegranate. Research

68 has evaluated the effect of $\mathrm{N}$ on the juice quality and the effect on the antioxidant properties but 69 very little on the $\mathrm{N}$ requirement for crop production and the effect of $\mathrm{N}$ levels on yield. Dhillon 70 (2011) evaluated the $\mathrm{N}$ requirement of developing pomegranate and found that increasing the 71 level of $\mathrm{N}$ from 0 to $60 \mathrm{~g} /$ tree/ year resulted in larger trees and yield for the highest $\mathrm{N}$ levels with 
72 the number of fruit and fruit size increasing as well. This was characterized as being a result of

73 the increase in tree size. The maximum $\mathrm{N}$ rate was equivalent to $36 \mathrm{~kg} / \mathrm{ha}$ of $\mathrm{N}$. Other studies on

74 mature trees estimated the $\mathrm{N}$ requirement as 500 to $625 \mathrm{~g} \mathrm{~N} /$ tree (Prabhakar, et al. 2006).

75 Current $\mathrm{N}$ usage in California is approximately 60 to $112 \mathrm{~kg} / \mathrm{ha}$ where $\mathrm{N}$ is commonly applied as

76 a split application in the winter and then in the spring. Initial studies didn't show any benefit to

77 yield, size and fruit quality from the application of $\mathrm{P}$ and K (La Rue, 1977)

78 Pomegranate is characterized as being drought tolerant but few studies have quantified the actual

79 water requirement. Kattah et al. (2011) found that the yield increased as the applied water

80 increased from 280 to $600 \mathrm{~mm}$ of applied water in a 20-year-old pomegranate orchard. Most

81 studies determined the water requirement for surface (furrow, sprinkler) irrigated crops using a

82 variety of water balance methods to determine evapotranspiration and to develop crop

83 coefficients for irrigation scheduling. Meshram et al. (2011) estimated the water requirement for

84 a pomegranate orchard up to five years of age using surface drip irrigation. They found the

85 maximum crop coefficient $\left(\mathrm{k}_{\mathrm{c}}\right)$ to be 1.18 and daily water use of $5.3 \mathrm{~mm} /$ day for a 5 -year-old

86 tree.

87 High level of nitrate $\left(\mathrm{NO}_{3}{ }^{-}\right)$in the groundwater is a significant problem in California aquifers

88 (Harter, et al. 2002; Harter et al. 2012) and irrigated agriculture has been identified as a

89 significant source of nitrate pollution. Nightingale (1972) sampled groundwater aquifers under

90 areas in grape, orchard, row crop production, and fallow and found a significant correlation

91 between the crop $\mathrm{N}$ management and the levels of nitrate in the soil profile and in the

92 groundwater. This was at a time when furrow irrigation was the principal irrigation method and

93 deep percolation losses were significant and would be the transport mechanism for nitrate. Since

94 that time drip irrigation has been widely adopted on many perennial crops and the potential for

95 nitrate transport has been significantly reduced with the implementation of improved irrigation

96 scheduling and irrigation system management. Research has shown that well- managed surface

97 drip irrigation (DI) and subsurface drip irrigation (SDI) systems can eliminate runoff, deep

98 drainage, minimize surface soil and plant evaporation, reduce transpiration of drought tolerant

99 crops, and significantly reduce fertilizer losses, thus protecting groundwater quality (Ayars, et al.

100 1999).

101 This project was initiated to determine the water and $\mathrm{N}$ requirements of a 6-year-old fully

102 irrigated pomegranate orchard using high frequency surface and subsurface drip irrigation.

\section{2. Materials and Methods}

104 This project was located on the University of California Kearney Agricultural Research and

105 Extension Center (KARE) on a 1.4 ha field that included a large weighing lysimeter (Phene, et

106 al. 1991; Ayars et al. 2003). Pomegranate trees (Punica granatum L. var. Wonderful) were

107 planted in 2010 with $4.9 \mathrm{~m}$ between row spacing and a within row spacing of $3.6 \mathrm{~m} \mathrm{(567}$ 
trees/ha). The orchard was laid out in a split-plot design with 2 irrigation methods as the main treatments and $3 \mathrm{~N}$ levels as the sub-treatments with 5 replicates (Fig. 1). Each plot contained 3 tree rows and a minimum of 7 trees per row. The center row was used as the experimental row with the center 5 trees being sampled for yield and fruit quality data. The trees were allowed to grow free form with multiple trunks (Day and Wilkins, 2011) with little pruning and the height maintained at approximately $3 \mathrm{~m}$.

The main treatments were surface drip irrigation (DI) and subsurface drip irrigation (SDI) with the drip laterals installed at a depth of $50-55 \mathrm{~cm}$. There were 2 drip laterals per tree row with a lateral located on each side of the tree row at a distance of $1.1 \mathrm{~m}$ from the row. The emitter discharge rate was $2 \mathrm{~L} / \mathrm{hr}$ spaced at $1 \mathrm{~m}$ apart along the lateral. The trees were irrigated after 1 $\mathrm{mm}$ of crop water use had been measured in the lysimeter. During peak crop water use this could result in up to 8-12 irrigations per day.

\section{Figure 1. Layout of experimental plots.}

132 Previous research (Bauer, et al. 2002; Liu, et al. 2011; Buckman and Brady, 1966) has shown 133 that phosphorus (P) can become deficient for a variety of crops at soil depths greater than $20 \mathrm{~cm}$. 134 To prevent $\mathrm{P}$ deficiency in this study phosphoric acid $\left(\mathrm{H}_{3} \mathrm{PO}_{4}, \mathrm{PO}_{4}-\mathrm{P}\right)$ was continuously injected 135 at a concentration of $\mathrm{P}=15-20 \mathrm{mg} / \mathrm{L}$ to maintain adequate $\mathrm{P}$ level in both the $\mathrm{DI}$ and SDI 136 treatments.

137 Previous research has shown that potassium may become extremely deficient in sandy loam soil 138 (Bauer, et al. 2002; Phene et al. 1989), especially as soil depth increases. In this study potassium $139\left(\mathrm{~K}_{2} \mathrm{~T}\right)$ was injected once weekly at a concentration of $\mathrm{K}=50 \mathrm{mg} / \mathrm{L}$ to maintain adequate $\mathrm{K}$ level in 140 both SDI and DI treatments. The total application of K was increased as the plants grew.

141 The soil profile was sampled in the spring and fall to a depth of $1.2 \mathrm{~m}$ in $15 \mathrm{~cm}$ increments in 142 each replication of each treatment and analyzed for nitrate using a 1:1 soil water extract and 143 filtered prior to analysis. The filtrate was analyzed using a colorimetric method (Mulvaney, 144 1996) with an Astoria 2 Analyzer (Astoria-Pacific Inc., Clackamas, OR, USA). Tree leaf samples 145 were collected biweekly from each treatment, dried at $42^{\circ} \mathrm{C}$, ground and analyzed for total $\mathrm{N}$. 
After harvest fruits were separated into arils and peels and were processed similar to the leaf samples and analyzed for total $\mathrm{N}$. The total $\mathrm{N}$ content in plant tissues was determined using a combustion method with a LECO TurMac CN Macro Determinator (LECO Corporation, St. Joseph, MI, USA).

There was only one tree on the lysimeter and it was irrigated using a SDI system with the same number of emitters (8) per tree as the remainder of the orchard. The lysimeter determined the water use for a fully irrigated (100\%) subsurface drip irrigation (SDI) with $\mathrm{N}$ treatment (N2) and automatically scheduled the irrigation for the field (Phene, et al., 1989). When the differential N treatments were begun in 2012 the water applied to the DI treatments was increased by $10 \%$ over

157 Reference evapotranspiration $\left(\mathrm{ET}_{\mathrm{o}}\right)$ was taken from nearby $(0.7 \mathrm{~km})$ California Irrigation 158 Management Information System (CIMIS) weather station and the crop water use $\left(\mathrm{ET}_{\mathfrak{c}}\right.$ ) was 159 measured by the weighing lysimeter. A crop coefficient $\left(\mathrm{K}_{\mathrm{c}}\right)$ was calculated daily as the ratio of $160 \mathrm{ET} / \mathrm{ET}_{\mathrm{o}}$. For irrigation scheduling the lysimeter water use was adjusted to account for the difference between the surface area of the lysimeter and the area for each field tree based on the

163 Precipitation was measured with a calibrated rain gauge installed next to the lysimeter, drainage 164 from the soil tank was measured using a tipping bucket rain gauge located at the drain outlet of 165 the lysimeter, and runoff was prevented by the design of the lysimeter tank. The water applied by the SDI and DI systems was measured with electronic water meters. We calibrated heat 167 dissipation soil water matric potential (SMP) sensors (CSI-229, Campbell Scientific Inc. Logan, 168 Utah, USA) to provide the SMP status of the soil in the lysimeter (Phene and Howell 1984).

169 These SMP sensors were installed in columns located in the north and south ends of the 170 lysimeter at depths of 0.6, 0.9, 1.2 and $1.5 \mathrm{~m}$ from the soil surface. The SMP data were averaged 171 by depth and were used to calculate the hydraulic gradient to determine the direction of water 172 flow in the root zone and to infer the leaching potential under high frequency SDI (Phene et al., 173 1989; Phene et al. 2015).

174 Rate of water flow and the direction of flow can be determined using Darcy's law (Smith and 175 Warrick, 2007). We calculated the gradient based on soil matric potential and depth of the sensor 176 within the soil profile using the SMP data

$$
\Delta \mathrm{H} / \Delta \mathrm{Z}=\left(H_{2}-H_{1}\right) /\left(Z_{2}-Z_{1}\right)
$$

178 with $\mathrm{H}=\Psi-Z$ where $\Psi$ is the soil matric potential, $\mathrm{H}$ is the head, and $\mathrm{Z}$ is the sensor depth.

179 This results in $\quad \Delta \mathrm{H} / \Delta \mathrm{Z}=\left(\Psi_{2}-\Psi_{1}\right) /\left(\mathrm{Z}_{2}-\mathrm{Z}_{1}\right)-1$ 
with $\left(\Psi_{2}-\Psi_{1}\right)$ being the SMP difference between 2 depths and $\left(Z_{2}-Z_{1}\right)$ is the corresponding soil depth difference measured downward from the soil surface and (-1) represents the gravitational component of the gradient. However, the downward flow due to gravity was insignificant due to the high frequency of irrigation with the SDI systems applying water at the rate being taken up by evapotranspiration. As a result, the equation 2 reduces to

\section{6}

$$
\Delta \mathrm{H} / \Delta \mathrm{Z}=\left(\Psi_{2}-\Psi_{1}\right) /\left(\mathrm{Z}_{2}-\mathrm{Z}_{1}\right)
$$

Pomegranate fruits were harvested annually in a single harvest by a local packer and subsamples were taken from the 5 center trees of each of the yield rows and measured for total number, weight, and quality. The quality designations were prime, subprime, green, marketable, and culls. For analysis we combined the various categories into prime and subprime fruit. The prime fruit included fruit with good color, minimal cracking with no open cracks, diameter greater than $8 \mathrm{~cm}$, and were marketable as fresh fruit. The subprime included fruit suitable for juicing, and contained some green and open cracked fruit. The sum of all the categories gave the total production.

Water productivity (WP) was calculated as the average yield for all $\mathrm{N}$ treatments per ha divided by the applied water in $\mathrm{mm}$ for the SDI and the DI systems. It was also calculated for the individual $\mathrm{N}$ treatments in each irrigation system by averaging the DI and SDI by $\mathrm{N}$ treatment for the prime, subprime, and total production. The $\mathrm{N}$ productivity (NP) was calculated by dividing the prime, subprime, and total yield by the total applied $\mathrm{N}$ for each treatment.

A split plot mixed model was fit using the SAS PROC MIXED program (SAS, 2013). Irrigation, $\mathrm{N}$ and their interaction are the fixed effects and the replications (reps) and irrigation by reps are random effects. Means were taken over the tree subsamples prior to analysis. The analysis included means and 95\% confidence intervals for the irrigation and $\mathrm{N}$ main effects and linear and quadratic contrasts for the $\mathrm{N}$ main effects. For $\mathrm{N}$ concentration data in tree leaf samples (sampled biweekly), the fixed effects are irrigation type, $\mathrm{N}$ rate, date, and their interactions and the random effects are block, irrigation type $\times$ block and irrigation type $\times \mathrm{N}$ rate $\times$ block; and this latter 3way interaction defines the experimental units for incorporating a first-order, autoregressive covariance structure among the repeated measures. Focus was on the significant irrigation type $\times \mathrm{N}$ rate interaction for which the least square means and their $95 \%$ confidence intervals were obtained. For $\mathrm{N}$ concentration data in fruit samples, the fixed effects and random effects are the same as the yield data analysis.

\section{Results}

\subsection{Crop Water Use}


217 The crop water balance is given in table 1 from 2010 to December 15, 2015. The water balance

218 data from the first 3 years $(2010$ - 2012) were included to characterize crop water use during

219 early plant development. The experiment ended in December 2015 when the trees were removed

220 from the field. There was cold weather prior to the tree removal in 2015 that resulted in leaf drop 221 and the cessation of transpiration prior to tree removal.

222 The total annual reference evapotranspiration $\left(\mathrm{ET}_{\mathrm{o}}\right)$ was lower in 2010-2011 than in 2012-2015.

223 From 2013 to 2015 there was approximately a 6\% variation in the total $\mathrm{ET}_{\mathrm{o}}$. The precipitation

224 values are below the regional averages of $250 \mathrm{~mm}$ due to the drought in the last 5 years of the

225 study. Most of the rainfall occurred during the winter which is typical of the Mediterranean

226 climate in the Central Valley of California.

227 Crop water use was increasing each year as the plants grew larger and the maximum daily use 228 increased to approximately 10 to $10.5 \mathrm{~mm}$ per day which is slightly higher than what was 229 reported by Meshram et al. (2011). The maximum crop coefficient $\left(\mathrm{K}_{\mathrm{c}}\right)$ increased from a 0.85 in 2302013 to 1 to 1.2 in 2015 which is lower than what was reported by Meshram et al. (2011). The 231 data for 2015 (Fig. 2) were used in the crop coefficient calculation since they represented a 232 mature tree. The crop coefficient was calculated as a 7-day running average of the ratio of the 2332015 crop water use data and reference potential evapotranspiration fitted with a $5^{\text {th }}$ order 234 polynomial

$$
\mathrm{K}_{\mathrm{c}}=-0.125-0.000585 \mathrm{x}+0.0001624 \mathrm{x}^{3}-1.452 \mathrm{E}^{-6} \mathrm{x}^{3}+5.314 \mathrm{E}^{-9} \mathrm{x}^{4}-7.13 \mathrm{E}^{-12} \mathrm{x}^{5}
$$

where $\mathrm{x}$ is the day of the year. There is quite a bit of variability in the crop coefficient. Also, note that the maximum $\mathrm{K}_{\mathrm{C}}$ occurs August and September and not during the hottest month (July) of the year. This is a result of the calculation when the plant water use is high late in the year and the potential evapotranspiration has reduced from peak values.

240 Table 1. approximately here

243 Equal depths of irrigation water were applied to the DI and SDI systems in 2010 and 2011 to 244 ensure good stand development and reasonably uniform plant size. The irrigation data for the DI and SDI systems show a progressive increase in applied water to meet crop water use which was expected as the trees matured and increased in size over the six-year period. The difference in SDI and DI applied water beginning in 2102 was a result of the deliberate addition of approximately $10 \%$ more water to the DI treatment than the SDI treatment to compensate for water loss due to surface evaporation and water use by weeds. The last two years $(2014-2015)$ show that the crop water use measured by the lysimeter is in the range of $912-952 \mathrm{~mm}$ which 
reflects the mature crop water requirement. The applied irrigation water was $932 \mathrm{~mm}$ for the DI system and $843 \mathrm{~mm}$ for the SDI system. The difference in applied water was by design and highlights a significant advantage of SDI over DI systems and a potential opportunity to conserve water without creating negative impacts on plant size or yield. Additional study will be required to determine if additional savings are possible through sustained reduction in SDI

256 treatment.

257 No drainage was measured from the lysimeter by the tipping bucket rain gauge installed in the lysimeter. The lack of drainage from the lysimeter resulted in part due to the high frequency irrigation with SDI based on the precise determination of the hourly crop water use. The ability to meet crop water demand with small applications of water minimizes the potential for deep percolation with SDI by meeting the crop water use and only requiring storage of small volumes of water compared to surface irrigation methods that may apply in excess of $250 \mathrm{~mm}$ in an irrigation. With high frequency irrigation, it is possible to control the soil matric potential (SMP) and thus the resulting hydraulic gradients with the net result being minimal to no deep percolation. The on-going drought during the experiment and lower than average rainfall during this period probably contributed to the lack of drainage particularly during the winter months when there was no crop demand and the majority of the rain occurs.

3.2. Soil Matric Potential (SMP) Measurements and Hydraulic Gradient (HG) in the SDI Irrigated Lysimeter:

With the concern for transport of nitrate to the groundwater it is essential to quantify the movement of water and $\mathrm{NO}_{3}{ }^{-}$through and below the crop root zone. Potential deep percolation and $\mathrm{N}$ transport through and below the crop root zone was determined using hydraulic gradients (HG) calculated from soil matric potential measurements (SMP) collected in the lysimeter.

274 Figure 3 shows the average SMP measurement at depths of $0.6 \mathrm{~m}, 0.9 \mathrm{~m}, 1.2 \mathrm{~m}$, and $1.5 \mathrm{~m}$ in 2013 (a), 2014 (b) and 2015 (c). The data show that the SMP was maintained in a range of -30 to $-45 \mathrm{kPa}$ in each year during the operation of the irrigation system which is a well-watered range for this Hanford sandy loam soil. The spike in the data in June of 2013 occurred when the irrigation system was not well controlled and excess water was applied. The spike in February 2104 was a result of a $33 \mathrm{~mm}$ rainfall. The subsequent decline in the soil matric potential was a result of the trees leafing out and using soil water. This is followed by the beginning of irrigation and the trees reaching full bloom about day 110. The spikes in the SMP demonstrate the sensitivity of the sensors to changes in water content. The SMP data for 2015 show the same

283 pattern of control within a narrow range of matric potential. 
288 Calculated daily averaged hydraulic gradients (HG) for 2013, 2014 and 2015 are shown in Fig. 4 $289 \mathrm{a}, \mathrm{b}$, and $\mathrm{c}(\mathrm{HG}>0$ indicates upward flux and $\mathrm{HG}<0$ indicate downward flux). HG-1 is the 290 gradient from 0.6 to $0.9 \mathrm{~m}$. HG-2 is the gradient from 0.9 to $1.2 \mathrm{~m}$ and HG-3 is the gradient from 2911.2 to $1.5 \mathrm{~m}$. Results in Fig. 4 indicate that HG-1 and HG-3 are positive each year with upward 292 flow while the zone from $0.9 \mathrm{~m}$ to $1.2 \mathrm{~m}$ has water moving downwards in each year. However, 293 the gradient from 1.2 to $1.5 \mathrm{~m}$ is upward thus preventing drainage and nitrate leaching (none 294 measured from the lysimeter). While these data were collected in the lysimeter, it is reasonable 295 to expect a similar flow situation in the field in both the DI and SDI systems since the irrigation 296 in the field was controlled by the lysimeter.

297 Figure 4. Hydraulic gradients of soil water flow

\subsection{Fertility Management}

299 In all year's most of the $\mathrm{N}$ was applied by mid-June to meet the large $\mathrm{N}$ demand at budbreak and 300 leaf and fruit development (Wang et al., 2015). After the initial injection of $\mathrm{N}$ early in the season 301 the remaining application is a result of the continuous injection of the US-10, which was used for $302 \mathrm{pH}$ control and to provide $\mathrm{N}$ for the N1 treatment.

303 The total applied N, P and K for the 3 years of the study are summarized in Table 2. The total 304 seasonal phosphorous application depended on the total applied water since it was injected 305 continuously at a constant level of $15 \mathrm{ppm}$ throughout the irrigation season. The total applied P 306 increased over (Bauer et al. 2002) the years in part due to the increased applied water to meet 307 crop water requirement.

309 Table 2 about here.

310 The applied fertilizers provided a wide range of total application to evaluate the response of yield 311 to applied fertilizer. The higher value of $\mathrm{K}$ in 2015 was the result of control problems with the 312 fertilizer injection pump.

\section{3.4. Yields, Water Productivity (WP) and N Productivity (NP):}

314 The yield data were statistically analyzed by averaging yields for each $\mathrm{N}$ treatment by irrigation 315 system and by averaging irrigation system (SDI, DI) yields within the N treatments (Table 3 ).

316 Table 3 here.

317 We evaluated the interactions between irrigation systems and $\mathrm{N}$ treatments, and between $\mathrm{N}$ 318 treatments in all three years. In 2013 there were statistical differences between the fruit weight of 
the prime and subprime fruit in the SDI and the DI systems. There was no difference in the total weight between the SDI and DI across the $3 \mathrm{~N}$ levels. In 2014 the prime yields were different by $\mathrm{N}$ treatments with yield increasing with applied $\mathrm{N}$. The opposite was true with the subprime yield and yield decreased as $\mathrm{N}$ increased. The net effect was that the total yield was not different across the $\mathrm{N}$ treatments. In 2015 the only effects that were identified were between irrigation system types. The subprime yield differed between DI and SDI but not between N treatments. There were no statistical differences in total yield in any of the years. The yield of prime fruit for 2014-2015 was between 31,563 to $40,731 \mathrm{~kg} / \mathrm{ha}$ which is in the comparable yield range reported in the literature (Rymon, 2015; Day and Wilkins, 2011). The total yield increased from an average of 34 MT in 2013 to 51 MT in 2015 in part due to the increase in plant size and additional fruit.

There were no consistent statistical trends across the 3 years of the study that demonstrate a yield response to increasing applied $\mathrm{N}$ or between irrigation systems. The average yield was consistently higher in the SDI system compared to the DI system but not statistically different. The total applied $\mathrm{N}$ at the $\mathrm{N} 1$ level ranged from 62 to $112.8 \mathrm{~kg} / \mathrm{ha}(109-198 \mathrm{~g} / \mathrm{tree})$ which is in 334 the range of current practice in California (LaRue, 1977).

The water productivity (WP) was calculated as the average yield for all $\mathrm{N}$ treatments per ha divided by the applied water in $\mathrm{mm}$ for the SDI and DI systems. This was done for the prime, subprime, and total production. These data are given in Table 4.

The data show that the WP was consistently higher in the SDI treatments than in the DI treatments. This was a result of the higher average yields in the SDI treatments than in the DI and lower values of applied water in SDI compared to DI each year. The WP values for the total yield were similar across the treatments in the 3 years of the study.

The yield data were sorted by $\mathrm{N}$ level and the SDI and DI yields were averaged at a given $\mathrm{N}$ level and the WP was calculated using the average applied water. These data are given in Table 5. In 2013 and 2014 the prime yields increased with increased applied $\mathrm{N}$ but the opposite demonstrated in 2015. There was no significant difference in total yield as a function of $\mathrm{N}$ level in any given year. The total yield increased from 2013 to 2015. This would be expected as the trees size increased. The WP was statistically different between years and not within years for

350 Table 5 here.

The N productivity (NP) data are summarized in Table 6 . The data show that SDI had a higher NP than the DI treatments in 2013 and 2014 but not in 2015. This can be explained in part due to 353 the placement of the $\mathrm{N}$ with the root zone with the SDI system which would improve the uptake 
354 by the plant. In each year the NP decreased with increasing levels of applied $\mathrm{N}$ since there was

355 no yield increase associated with the increased levels of applied $\mathrm{N}$. The N1 treatment had the

356 highest value of NP in each year demonstrating that 62 to $112 \mathrm{~kg}$ of N per ha will maintain yield

357 which is consistent with other research (Dhillon et al. 2011). In all years, the N1 treatment had

358 yield values equal to the higher $\mathrm{N}$ treatments $(\mathrm{N} 2, \mathrm{~N} 3)$.

359 Table 6 here

360 All fruit were lumped together to determine the average yield per tree and fruit weight for each 361 of the $\mathrm{N}$ treatments and irrigation systems. These data are given in Table 7 . The yield per tree

362 increased from 2013 to 2015 for the $\mathrm{N}$ treatments averaged by irrigation system. There was no

363 difference in yield by $\mathrm{N}$ treatment within a given year. This is true for the yields by $\mathrm{N}$ and

364 irrigation treatment over the year. The average fruit size was the same within treatments in a

365 given year.

366 Table 7 here.

367 3.5. Plant N Uptake

368 Total $\mathrm{N}$ content was analyzed in pomegranate leaves sampled biweekly during the course of 369 the field experiment. The 2015 data are provided here to demonstrate $\mathrm{N}$ content changes after 370 trees had reached a mature stage (Fig. 5). The tree leaf $\mathrm{N}$ concentration started high in new 371 leaves in spring time and reduced slightly over the growing season for all treatments. Statistical 372 analysis showed significant differences caused by $\mathrm{N}$ rate, sampling date, and Irrigation type $\mathrm{x}$ 373 N rate. Figure 5 clearly shows that the N1 rate resulted in lower responses than N2 and N3 374 rates for both irrigation types and that the differences were greater for the DI irrigation type 375 than that for the SDI. The data indicate that the N2 application had likely maximized the $\mathrm{N}$ 376 uptake by pomegranate trees.

\section{$377 \quad$ Figure 5}

$378 \mathrm{~N}$ content in pomegranate fruits, separated into peels and arils, were determined after harvest in 3792014 and the averages for all six treatments are plotted in Fig. 6. The concentration ranged from $380 \quad 0.7-0.9 \%$ in peels and $1.0-1.4 \%$ in arils. For the $\mathrm{N}$ in peels, there was significant effect of $\mathrm{N}$ rate, 381 but no significant effect of irrigation type and irrigation $\mathrm{x} N$ rate interaction. The $\mathrm{N} 1$ resulted in 382 significantly lower $\mathrm{N}$ concentration than those from $\mathrm{N} 2$ and $\mathrm{N} 3$ with no differences between the 383 two higher rates. For the $\mathrm{N}$ concentration in arils, however, no significance was attained for any 384 of the fixed effects. The data imply that regardless of the differences in tree leaves and fruit 385 peels, $\mathrm{N}$ content in arils (the edible part) in $\mathrm{N} 1$ rate were not any different from the higher rates.

386 Figure 6. 
Although some differences were determined in pomegranate fruit $\mathrm{N}$, there were no differences observed in fruit yield (Table 3) between any of the three $\mathrm{N}$ application levels. As the orchard reached a mature stage in 2015, the $\mathrm{N}$ application rate at $\mathrm{N} 1$ was $112 \mathrm{~kg} / \mathrm{ha}$ when no differences in leaf $\mathrm{N}$ were found between the $\mathrm{N} 1$ and higher $\mathrm{N}$ levels especially under SDI. The data support the estimates that the $\mathrm{N}$ requirement for a mature pomegranate orchard can be approximated at $62-112 \mathrm{~kg} / \mathrm{ha}$ for SDI, and higher for DI, which could be caused by insufficient $\mathrm{N}$ uptake. The $\mathrm{N}$ application rate at N2 was above $200 \mathrm{~kg} / \mathrm{ha}$ in 2014 and 2015 (Table 2) which was considered to be excessive because of the little difference in leaf and fruit $\mathrm{N}$ between $\mathrm{N} 2$ and $\mathrm{N} 3$. It is unknown if the low $\mathrm{N}$ level in fruits would affect fruit quality which was not determined in this study. Total $\mathrm{N}$ concentration data show no significant differences in arils among the three $\mathrm{N}$ rates.

\subsection{Soil Nitrate Profiles.}

The fate of $\mathrm{N}$ and nitrate movement is a significant environmental concern in irrigated agriculture and is determined by both the placement and the total application of $\mathrm{N}$ fertilizers. 401 N injection with SDI places nitrate below the soil surface and within the tree root zone which 402 facilitates crop uptake. A DI system applies the water and thus $\mathrm{N}$ to the soil surface which 403 requires transport to the root zone and increases the opportunity for loss through volatilization 404 and denitrification.

405 The distribution of the average nitrate from all three $\mathrm{N}$ treatments by irrigation system for each 406 of the sampling dates is given in Fig. 7. The differential N treatments were begun in 2012. The 407 nitrate distribution throughout the soil profile in both the SDI and DI systems were similar as 408 can be seen by comparing the nitrate distribution in Fig. 7a and 7b for March 2013.

$409 \quad$ Figure 7.

410 Fig. 7a gives the distribution under the surface drip irrigation system. All the fertilizers were 411 applied through the drip irrigation and were applied to the soil surface. The lowest profile 412 concentrations occurred in March 2013. There was a gradual increase in concentration 413 throughout the profile over time with the highest levels occurring at $1.2 \mathrm{~m}$ in January of 2015. 414 Recall that the net hydraulic gradients measured in the lysimeter for this portion of the profile 415 were upwards and potentially minimized the $\mathrm{N}$ transport deeper in the profile.

416 The data in Fig $7 \mathrm{~b}$ is for the SDI system with all the $\mathrm{N}$ treatments averaged at each depth. The 417 SDI system is installed at 50 to $55 \mathrm{~cm}$ below the soil surface and most of the $\mathrm{N}$ is located 418 above the drip system. The average concentration at $1.2 \mathrm{~m}$ is significantly lower at the end of 419 the experiment in this system than in the surface drip system. This is a result of the injection of 420 the nutrients close to the roots. Recall that the hydraulic gradients measured in the lysimeter 421 for this portion of the profile were upwards and potentially minimizes the transport deeper in 
422 the profile. Comparing the two systems there is the potential for significantly less $\mathrm{N}$ being lost 423 to deep percolation with the SDI than the DI system.

424 3.7. Weed population under DI and SDI

425 One of the advantages of SDI is the potential for lower weed populations than with surface 426 drip as shown in September of 2012 (Fig. 8). We evaluated this proposition in 2013 by 427 sampling and drying the total weed mass in a square meter in each replicate. The residual 428 weed biomass in the pomegranate orchard was measured on August 28, 2013 after herbicide 429 burn-down and results are shown in Table 8. Results indicate that the weed biomass in the SDI 430 treatment was significantly lower than that in the DI treatment. The relationship between 431 weeds and the soil temperature at solar noon were measured on Sept. 3, 2013 and there was a 432 significant relationship. $\mathrm{R}=-0.636, P=0.0002$. The infrared soil surface temperature was 433 significantly higher in the SDI than in the DI treatments due to lack of weeds.

434 Table 8 here.

435 Figure 8. Differences in weed population between DI and SDI irrigated pomegranate.

436 Measurement of the weed mass was not conducted for other growing seasons but we observed 437 that the weed mass was consistently greater in the DI than in the SDI treatments as would be 438 expected.

\section{4. Discussion}

440 As noted in the introduction there has been very little research to describe the $\mathrm{N}$ and water 441 requirements and most of the literature comes from research in India, Israel and Spain.

442 Previously, the water requirements were based on pan evaporation and estimated

443 evapotranspiration using and energy balance equation. The irrigation systems used included

444 surface drip and surface irrigation (furrow, basin) which have very different efficiencies which 445 may affect the estimates. Part of the challenge is the lack of standardization with row and tree 446 spacing. Firake and Kumhbar (2002) used a 4 by $4 \mathrm{~m}$ spacing for rows and trees within rows 447 with the resulting density of 625 trees/ha. This compares to 567 trees in this experiment. They 448 estimated that the crop water requirement of an 8-year-old tree cultivar G-137 was $789 \mathrm{~mm}$ for 449 surface drip and $1129 \mathrm{~mm}$ for surface irrigation. Crop water use was estimated at 0.75 of pan 450 evaporation during Ambe Bahar season which is equivalent to 12, $624 \mathrm{~L} /$ tree. Meshram et al. 451 (2012) estimated the water use for a 5-year-old tree during this same period to be 11,949 452 L/tree using the Penman- Montieth equation. The crop water use measured with the weighing 453 lysimeter was $843 \mathrm{~mm}$ which is equivalent to $14,867 \mathrm{~L} /$ tree for a SDI irrigated tree. 
454 Friake and Kumbhar (2002) reduced the applied water by $80 \%$ in the drip irrigated plot. The result was significantly smaller fruit compared to this research. The fruit were approximately

$45650 \%$ of the size of the fruit in this study.

457 Given the competition for water between agricultural and municipal interests, irrigation should 458 be done using the most efficient system available typically pressurize systems e.g. sprinklers, 459 drip irrigation. We demonstrated that high frequency drip irrigation was effective in reducing 460 deep percolation losses and that additional reductions were possible with the use of subsurface 461 drip irrigation. We demonstrated the ability to manage $\mathrm{N}$ in the root zone and minimize deep 462 percolation losses and $\mathrm{N}$ transport.

463 Yields varied widely throughout the world with average yields less than $11.2 \mathrm{~T} / \mathrm{ha}$ in India and $464>40 \mathrm{~T} / \mathrm{ha}$ in Israel, Spain and Turkey. The yields from this study ranged an average of 34.3 $465 \mathrm{~T} / \mathrm{ha}$ in 2013 to $51.2 \mathrm{~T} / \mathrm{ha}$ on 2015 and were typical of yield averages in California (Day and 466 Wilkins 2011).

467 The N:P:K requirements typically set at 625:250:250 g/tree (Prabhakar, et al. 2006) which is a 468 significantly larger requirement for $\mathrm{N}$ than was demonstrated in this study with a range of 109 $469-198 \mathrm{~g} /$ tree as the plant developed. The use of $\mathrm{g} /$ tree is probably the best way to characterize 470 the $\mathrm{N}$ requirement, since there are no established practices for tree and row spacing (Day and 471 Wilkins 2011) in California or throughout the world and specifying $\mathrm{N}$ requirements on an area 472 basis may result in significant over-fertilization. The fruit quality was not affected by 473 increasing the $\mathrm{N}$ above the lowest level as demonstrated by the $\mathrm{N}$ content in the arils. There 474 were increases in the leaf and woody tissue with increased $\mathrm{N}$ application but not in the arils 475 that are the edible portions of the fruit.

\section{Conclusions}

High frequency surface (DI) and subsurface drip irrigation (SDI) were used to determine the water and $\mathrm{N}$ requirements of a developing pomegranate orchard. We determined that the water requirement of a 6-year-old multi-trunk tree was $953 \mathrm{~mm}$ using a weighing lysimeter and the peak daily water use was $10.5 \mathrm{~mm}$. The crop coefficient was described using a 5th order polynomial based on the day of the year. The difference in applied water between the DI and SDI $(843 \mathrm{~mm}$ vs $932 \mathrm{~mm}$ ) did not result in any negative effects on crop yield and fruit quality in any year. Subsurface drip irrigation can be used to irrigate pomegranate.

The $\mathrm{N}$ requirement was determined to be in the range of 62 to $112 \mathrm{~kg} / \mathrm{ha}(109-198 \mathrm{~g} /$ tree $)$. There was no increased yield and increased $\mathrm{N}$ content in fruit arils in response to $\mathrm{N}$ applied in excess of $112 \mathrm{~kg} / \mathrm{ha}$. There was a consistent non-statistical difference in yield between the SDI and DI systems with the SDI out producing the DI systems. Water productivity was statistically 
different across each year but not within $\mathrm{N}$ levels within a year. $\mathrm{N}$ productivity was higher in the

490 SDI systems because of the higher yields in the SDI system compared to the DI system. The NP

491 was highest with the lowest applied $\mathrm{N}$ since there was no yield response to increased $\mathrm{N}$

492 applications.

493 The use of high frequency subsurface drip irrigation resulted in no deep percolation losses

494 measured at a depth of $1.5 \mathrm{~m}$ in a weighing lysimeter during the 5 years of the experiment. Soil

495 matric potential was maintained within a narrow range during the irrigation season using high

496 frequency drip irrigation which contributed to controlling deep percolation losses. Use of

497 subsurface drip irrigation resulted in reduced weed pressure compared to surface drip irrigation.

\section{Acknowledgements}

499 The authors thank Mr. Richard Schoneman, Ms Aileen Hendrata, Mr. Scott Freund, Mr. Jim

500 Gartung, and Ms Stella Zambruzski for all the technical and field support they provided for this

501 project. Dr. Rebecca Tirado-Corbala analysing plant and soil samples for carbon and nitrogen

502 content. The authors also thank the following companies and agencies for support of this

503 project:CDFA/FREP Fertilizer Research and Education Program - funding (3 years), Wonderful

504 Orchards- trees, Lakos - Media filter set, Toro Micro Irrigation - Rootguard drip tubing,

505 Verdegaal Brothers - Fertilizers, Dorot Valves - Solenoid \& Manual valves, and Dr. Erik

506 Wilkins, Wonderful Orchards, SDI+- Consulting Time \& equipment.

508 "The U.S. Department of Agriculture (USDA) prohibits discrimination in all its programs and 509 activities on the basis of race, color, national origin, age, disability, and where applicable, sex, 510 marital status, familial status, parental status, religion, sexual orientation, genetic information, 511 political beliefs, reprisal, or because all or part of an individual's income is derived from any 512 public assistance program. (Not all prohibited bases apply to all programs.) Persons with 513 disabilities who require alternative means for communication of program information (Braille, 514 large print, audiotape, etc.) should contact USDA's TARGET Center at (202) 720-2600 (voice 515 and TDD). To file a complaint of discrimination, write to USDA, Director, Office of Civil 516 Rights, 1400 Independence Avenue, S.W., Washington, D.C. 20250-9410, or call (800) 7955173272 (voice) or (202) 720-6382 (TDD). USDA is an equal opportunity provider and employer."

\section{References}

520 Al-Muammar, M., and F. Khan. 2012. Obesity: The preventive role of the pomegranate (Punica 521 Granatum). Nutrition, 28(6), 595-604. 
Ayars, J. E., R. S. Johnson, C. J. Phene, T. J. Trout, D. A. Clark and R. M. Mead. 2003. Crop water use by late season drip irrigated peaches. Irrigation Science 22: 187-194.

Ayars, J.E., C.J. Phene, R.B. Hutmacher, K.R, Davis, R.A. Schoneman, S.S. Vail, and R.M. Mead. 1999. Subsurface drip irrigation of row crops: a review of 15 years of research at the Water Management Research Laboratory. Agricultural Water Management. 42:1-27.

Basu, A. and K. Penugonda. 2008. Pomegranate juice: a heart-healthy fruit juice. Nutrition Reviews. 67(1): 49-56.

Bauer, P. J., J. R. Frederick and W. J. Busscher. 2002. Tillage effect on nutrient stratification in narrow- and wide-row cropping systems. Soil and Tillage_Research 66(2): 175-182.

Buckman, H.O., and N.C. Brady. 1966. The nature and properties of soils. The Macmillan Company, New York, NY. 567pg.

Day, K. R. and E. D. Wilkins. 2011. Commercial pomegranate (Puncia Granatum L.) production in California, International Society for Horticultural Science (ISHS), Leuven, Belgium. Pg. 275285

Dhillon, W. S., P. P. S. Gill and N. P. Singh. 2011. Effect of nitrogen, phosphorus, and

Galindo, A., Á. Calín-Sánchez, J. Collado-González, S. Ondoño, F. Hernández, A. Torrecillas and Á. A. Carbonell-Barrachina. 2014. Phytochemical and quality attributes of pomegranate fruits for juice consumption as affected by ripening stage and deficit irrigation. Journal of the potassium fertilization on growth, yield, and quality of pomegranate "Kandhari" International Society for Horticultural Science (ISHS), Leuven, Belgium. Pg. 327-332. Science of Food and Agriculture 94(11): 2259-2265.

Harter, T., H. Davis, M. C. Mathews and R. D. Meyer. 2002. Shallow groundwater quality on dairy farms with irrigated forage crops. Journal of Contaminant Hydrology 55(3-4): 287-315. A. D. Hollander, K. L. Honeycutt, M. W. Jenkins, V. B. Jensen, A. M. King, G. Kourakos, D. Liptzin, E. M. Lopez, M. M. Mayzelle, A. McNally, J. Medellin-Azuara, and T. S. Rosenstock, 2012. Addressing Nitrate in California's Drinking Water with A Focus on Tulare Lake Basin and Salinas Valley Groundwater, Report for the State Water Resources Control Board Report to the Legislature, Center for Watershed Sciences, University of California, Davis, 87p. 
Kattah, M. M., A. E. Shaban, A. H. El-Shrief and A. S. El-Deen Mohamed. 2011. Growth and

559 Productivity of Pomegranate Trees under Different Irrigation Levels I: Vegetative Growth and

560 Fruiting. Journal of Horticultural Science and Ornamental Plants_3(2): 194-198.

La Rue, J.H. 1977. Growing pomegranates in California. DANR Leaflet 2459. 6 pg.

Li, Z., P. H. Summanen, T. Komoriya, S. M. Henning, R.-P. Lee, E. Carlson, D. Heber and S. M. Finegold. 2015. Pomegranate ellagitannins stimulate growth of gut bacteria in vitro: Implications

for prebiotic and metabolic effects. Anaerobe 34: 164-168.

Liu, K., T. Q. Zhang and C. S. Tan. 2011. Processing tomato phosphorus utilization and postharvest soil profile phosphorus as affected by phosphorus and potassium additions and drip irrigation. Canadian Journal of Soil Science 91(3): 417-425.

Mertens-Talcott, S. U., P. Jilma-Stohlawetz, J. Rios, L. Hingorani and H. Derendorf .2006. Absorption, Metabolism, and Antioxidant Effects of Pomegranate (Punica granatum L.) Polyphenols after Ingestion of a Standardized Extract in Healthy Human Volunteers. Journal of Agricultural and Food Chemistry 54(23): 8956-8961.

Meshram, D. T., H. K. Mittal, R. C. Purohit, and S. D. Gorantiwar. 2011. Water Requirement of Pomegranate (Punica Granatum L.) for Solapur District of Maharashtra_State, International Society for Horticultural Science (ISHS), Leuven, Belgium. Pg. 311- 322.

Mulvaney R.S. 1996. Nitrogen-Inorganic forms. In: D.L. Sparks (ed.) Methods of soil analysis. Part 3. SSSA Book Series 5. SSSA, Madison, WI, pg. 1123-1184.

Nightingale, H. I. 1972. Nitrates in soil and ground water beneath irrigated and fertilized crops. Soil Science 114(4): 300 - 311.

Phene, C. J. and T. A. Howell. 1984. Soil Sensor Control of High-Frequency Irrigation Systems. Transactions of the ASAE 27(2): 392-396.

Phene, C.J., R.L. McCormick, K.R. Davis, J. Pierro, and D.W. Meek. 1989. A Lysimeter feedback irrigation controller system for evapotranspiration measurements and real time irrigation scheduling. Trans of the ASAE 32(2):477-484.

Phene, C.J., G.J. Hoffman, T.A. Howell, D.A. Clark, R.M. Mead, R.S. Johnson and L.E. Williams. 1991. Automated Lysimeter For Irrigation and Drainage Control. Proceeding of the Int. Symposium on Lysimetry, Honolulu, Hawaii, ASCE pp 28-36.

Phene, C.J., J.E. Ayars, R.C. Phene and R.S Schoneman. 2015. Irrigating and fertigating with high frequency subsurface drip irrigation can prevent drainage and groundwater contamination. ASABE Conf. Proceedings, Paper \# 152146263. 
597 Prabhakar, P., A. K. Singh and S. Kamiesh. 2006. Irrigation and fertigation of pomegranate cv.

598 Ganesh in Chhattisgarh. Indian J. of Horticulture 63(2): 148 - 151

599 Rymon, D. 2015. On the economics and marketing of pomegranates in Israel. Acta Horticulturae 600 1089:189-196.

601 SAS Institute Inc. 2013. SAS OnlineDoc® 9.4. Cary, NC: SAS Institute Inc.

602 Smith, R. E. and A. W. Warrick. 2007. Soil water relationships. Chapter 6. Design and Operation 603 of Farm Irrigation Systems. G. J. Hoffman, R. G. Evans, M. E. Jensen, D. L. Martin and R. L. 604 Elliot. 2950 Niles Rd., St. Joseph Michigan, American Society of Agricultural and Biological 605 Engineers: 120-159.

606

607 Stover, E. and E. W. Mercure. 2007. The Pomegranate: A new look at the fruit of paradise.

608 HortScience 42(5): 1088-2007.

609

610 Wang, D., J. Ayars, R. Tirado-Corbala, D. Makus, C.J. Phene, and R. Phene. 2015. Water and 611 nitrogen management of young and maturing pomegranate trees. Acta Horticulturae 1089:395612401.

613

614

615

616

617

618

619

620

621

622

623

624

625

626

627

628 
629 Table 1.Yearly water balance data 2010 to December 15, 2015 for surface (DI) and subsurface 630 (SDI) drip irrigated pomegranate measured with a weighing lysimeter irrigated with SDI.

\begin{tabular}{ccccccc}
\hline Year & $\begin{array}{c}\mathrm{ET}_{\mathrm{o}} \\
(\mathrm{mm})\end{array}$ & $\begin{array}{c}\text { Precipitation } \\
(\mathrm{mm})\end{array}$ & $\begin{array}{c}\mathrm{DI} \\
(\mathrm{mm})\end{array}$ & $\begin{array}{c}\text { SDI } \\
(\mathrm{mm})\end{array}$ & $\begin{array}{c}\mathrm{ET}_{\mathrm{c}} \\
(\mathrm{mm})\end{array}$ & $\begin{array}{c}\text { Drainage } \\
(\mathrm{mm})\end{array}$ \\
\hline 2010 & 1262.8 & 439.4 & 25.4 & 25.4 & 53.3 & $\mathrm{n} / \mathrm{a}$ \\
2011 & 1292.9 & 264.2 & 215.9 & 215.9 & $248.9^{*}$ & 0 \\
2012 & 1386.8 & 228.6 & 472.4 & 426.7 & 482.6 & 0 \\
2013 & 1397.0 & 81.3 & 645.2 & 584.2 & 683.3 & 0 \\
2014 & 1468.1 & 218.4 & 848.4 & 779.8 & 911.9 & 0 \\
$2015^{* *}$ & 1379.2 & 167.6 & 932.2 & 843.3 & 952.5 & 0 \\
\hline
\end{tabular}

$631 * \mathrm{ET}_{\mathrm{c}}$ measured from 5/1-12/8/11 only

$632{ }^{* *}$ As of: Dec. 15, 2015 when project ended.

633 
635 Table 2. Summary of applied N treatments (N1, N2, N3) and phosphorous (P) and potassium $636(\mathrm{~K})$.

\begin{tabular}{llllll}
\hline Year & $\mathrm{N} 1(\mathrm{~kg} / \mathrm{ha})$ & $\mathrm{N} 2(\mathrm{~kg} / \mathrm{ha})$ & $\mathrm{N} 3(\mathrm{~kg} / \mathrm{ha})$ & $\mathrm{P}(\mathrm{kg} / \mathrm{ha})$ & $\mathrm{K}(\mathrm{kg} / \mathrm{ha})$ \\
\hline 2013 & 69.8 & 166.3 & 244.5 & 65.5 & 72.8 \\
2014 & 62.0 & 223.3 & 341.7 & 91.8 & 85.2 \\
2015 & 112.8 & 263.3 & 331.4 & 116.0 & 181.0 \\
\hline
\end{tabular}

637

638 
639 Table 3. Summary of average prime and subprime and total yields for 2013, 2014 and 2015 by

640 irrigation system (DI and SDI) and N levels N1, N2, and N3.

\begin{tabular}{|c|c|c|c|c|c|c|c|c|}
\hline Year & $\begin{array}{l}\text { Irrigation } \\
\text { System }\end{array}$ & $\begin{array}{l}\text { Prime } \\
\text { (kg/ha) }\end{array}$ & $\begin{array}{l}\text { Sub } \\
\text { Prime } \\
\text { (kg/ha) }\end{array}$ & $\begin{array}{l}\text { Total } \\
\text { (kg/ha) }\end{array}$ & $\begin{array}{l}\mathrm{N} \\
\text { treatmen } \\
\mathrm{t}\end{array}$ & $\begin{array}{l}\text { Prime } \\
\text { (kg/ha) }\end{array}$ & $\begin{array}{l}\text { Sub } \\
\text { Prime } \\
\text { (kg/ha) }\end{array}$ & $\begin{array}{l}\text { Total } \\
\text { (kg/ha) }\end{array}$ \\
\hline \multirow[t]{3}{*}{2013} & SDI & $24566.1 a$ & 10697.1a & 35263.2 & N1 & 21638.4 & 11413.9 & 33052.3 \\
\hline & DI & $22850.2 b$ & $10360.0 b$ & 33210.2 & N2 & 24061.0 & 10506.7 & 34567.7 \\
\hline & & & & & N3 & 25552.8 & 9676.8 & 35229.6 \\
\hline \multirow[t]{3}{*}{2014} & SDI & 37369.9 & 10224.5 & 47594.4 & N1 & $31562.7 a$ & $13520.6 a$ & 45083.4 \\
\hline & DI & 33572.0 & 11772.3 & 45344.3 & N2 & $34118.6 b$ & $10755.4 b$ & 44872.8 \\
\hline & & & & & N3 & $40731.0 c$ & $8721.4 c$ & 49452.5 \\
\hline \multirow[t]{3}{*}{2015} & SDI & 40917.0 & $9440.5 a$ & 50357.4 & N1 & 38651.2 & 13070.4 & 51721.6 \\
\hline & DI & 33747.8 & $18245.9 b$ & 51993.8 & $\mathrm{~N} 2$ & 37273.6 & 13227.2 & 50501.9 \\
\hline & & & & & N3 & 36070.7 & 15232.0 & 51302.7 \\
\hline
\end{tabular}

641 Letters $(a, b, c)$ following the numbers indicate significance at $\mathrm{P}=0.05$ level.

642 
643 Table 4. Water productivity (WP) for prime, subprime, and total production for subsurface drip 644 irrigation (SDI) and surface drip irrigation (DI).

\begin{tabular}{lccccccc}
\hline Year & $\begin{array}{c}\text { Irrigation } \\
\text { System }\end{array}$ & $\begin{array}{c}\text { Prime } \\
(\mathrm{kg} / \mathrm{ha})\end{array}$ & $\begin{array}{c}\text { WP } \\
(\mathrm{kg} / \mathrm{ha} / \mathrm{mm})\end{array}$ & $\begin{array}{c}\text { SubPrime } \\
(\mathrm{kg} / \mathrm{ha})\end{array}$ & $\begin{array}{c}\text { WP } \\
(\mathrm{kg} / \mathrm{ha} / \mathrm{mm})\end{array}$ & $\begin{array}{c}\text { Total } \\
(\mathrm{kg} / \mathrm{ha})\end{array}$ & $\begin{array}{c}\text { WP } \\
(\mathrm{kg} / \mathrm{ha} / \mathrm{mm})\end{array}$ \\
\hline 2013 & SDI & 24566.1 & 42.1 & 10697.1 & 18.3 & 35263.2 & 60.4 \\
& DI & 22850.2 & 35.4 & 10360 & 16.1 & 33210.2 & 51.5 \\
2014 & SDI & 37369.9 & 47.9 & 10224.5 & 13.1 & 47594.4 & 61.0 \\
& DI & 33572 & 39.6 & 11772.3 & 13.9 & 45344.3 & 53.4 \\
& SDI & 40917 & 48.5 & 9440.5 & 11.2 & 50357.4 & 59.7 \\
\end{tabular}

645

646 
647 Table 5. Water productivity (WP) for N treatments (N1. N2, N3) averaged across irrigation 648 systems.

\begin{tabular}{llllllll}
\hline Year & $\begin{array}{l}\mathrm{N} \\
\text { treatment }\end{array}$ & $\begin{array}{l}\text { Prime } \\
(\mathrm{kg} / \mathrm{ha})\end{array}$ & $\begin{array}{l}\mathrm{WP} \\
(\mathrm{kg} / \mathrm{ha} / \mathrm{mm})\end{array}$ & $\begin{array}{l}\text { Sub Prime } \\
(\mathrm{kg} / \mathrm{ha})\end{array}$ & $\begin{array}{l}\mathrm{WP} \\
(\mathrm{kg} / \mathrm{ha} / \mathrm{mm})\end{array}$ & $\begin{array}{l}\text { Total } \\
(\mathrm{kg} / \mathrm{ha})\end{array}$ & $\begin{array}{l}\text { WP } \\
(\mathrm{kg} / \mathrm{ha} / \mathrm{mm})\end{array}$ \\
\hline 2013 & $\mathrm{~N} 1$ & 21638.4 & 35.2 & 11413.9 & 18.6 & 33052.3 & $53.8 \mathrm{a}$ \\
& $\mathrm{N} 2$ & 24061.0 & 39.1 & 10506.7 & 17.1 & 34567.7 & $56.2 \mathrm{a}$ \\
& $\mathrm{N} 3$ & 25552.8 & 41.6 & 9676.8 & 15.7 & 35229.6 & $57.3 \mathrm{a}$ \\
\hline 2014 & $\mathrm{~N} 1$ & 31562.7 & 38.8 & 11413.9 & 18.6 & 45083.4 & $73.3 \mathrm{~b}$ \\
& $\mathrm{~N} 2$ & 34118.6 & 41.9 & 10506.7 & 17.1 & 44872.8 & $73.0 \mathrm{~b}$ \\
& $\mathrm{~N} 3$ & 40731.0 & 50.0 & 9676.8 & 15.7 & 49452.5 & $80.4 \mathrm{~b}$ \\
\hline 2015 & $\mathrm{~N} 1$ & 38651.2 & 43.5 & 13070.4 & 21.3 & 51721.6 & $84.1 \mathrm{c}$ \\
& $\mathrm{N} 2$ & 37273.6 & 42.0 & 13227.2 & 21.5 & 50501.9 & $82.2 \mathrm{c}$ \\
& $\mathrm{N} 3$ & 36070.7 & 40.6 & 15232.0 & 24.8 & 51302.7 & $83.5 \mathrm{c}$ \\
\hline
\end{tabular}

649 Letters $(\mathrm{a}, \mathrm{b}, \mathrm{c})$ following numbers indicate significance at $\mathrm{P}=0.05$ level. 
651 Table $6 . \mathrm{N}$ productivity (NP) calculated as the yield in $\mathrm{kg} /$ ha divided by the total $\mathrm{N}$ applied in $652 \mathrm{~kg} / \mathrm{ha}$.

\begin{tabular}{llrrrrrrr}
\hline \multirow{2}{*}{ Year } & $\begin{array}{l}\text { Irrigation } \\
\text { System }\end{array}$ & Prime & $\begin{array}{l}\text { Sub } \\
\text { Prime }\end{array}$ & Total & $\begin{array}{l}\text { N } \\
\text { treatment }\end{array}$ & Prime & $\begin{array}{l}\text { Sub } \\
\text { Prime }\end{array}$ & Total \\
\hline 2013 & SDI & 153.3 & 66.8 & 220.1 & $\mathrm{~N} 1$ & 310.0 & 163.5 & 473.5 \\
& DI & 153.3 & 64.7 & 207.3 & $\mathrm{~N} 2$ & 144.7 & 63.2 & 207.9 \\
& & & & & $\mathrm{~N} 3$ & 104.5 & 39.6 & 144.1 \\
\hline 2014 & SDI & 178.8 & 48.9 & 227.7 & $\mathrm{~N} 1$ & 509.1 & 218.1 & 727.2 \\
& DI & 160.6 & 56.3 & 217.0 & $\mathrm{~N} 2$ & 152.8 & 48.2 & 201.0 \\
& & & & & $\mathrm{~N} 3$ & 119.2 & 25.5 & 144.7 \\
\hline 2015 & SDI & 173.5 & 40.0 & 213.5 & $\mathrm{~N} 1$ & 342.7 & 115.9 & 458.5 \\
& DI & 143.1 & 77.4 & 220.5 & $\mathrm{~N} 2$ & 141.6 & 50.2 & 191.8 \\
& & & & & $\mathrm{~N} 3$ & 108.8 & 46.0 & 154.8 \\
\hline
\end{tabular}

653

654

655 
656 Table 7. Average yield per tree and fruit weight for all the irrigation and $\mathrm{N}$ treatments for 2013, 6572014 , and 2015.

\begin{tabular}{lllllll}
\hline Year & $\begin{array}{l}\text { Irrigation } \\
\text { System }\end{array}$ & $\begin{array}{l}\text { Yield } \\
(\mathrm{kg} / \mathrm{tree})\end{array}$ & $\begin{array}{l}\text { Average } \\
\text { Fruit } \\
\text { wt. }(\mathrm{kg})\end{array}$ & $\begin{array}{l}\mathrm{N} \\
\text { treatment }\end{array}$ & $\begin{array}{l}\text { Yield } \\
(\mathrm{kg} / \mathrm{tree})\end{array}$ & $\begin{array}{l}\text { Average } \\
\text { Fruit wt. } \\
(\mathrm{kg})\end{array}$ \\
\hline 2013 & SDI & 62.9 & 0.42 & $\mathrm{~N} 1$ & 69.4 & 0.46 \\
& $\mathrm{DI}$ & 60.5 & 0.40 & $\mathrm{~N} 2$ & 67.6 & 0.45 \\
& & & & $\mathrm{~N} 3$ & 69.1 & 0.46 \\
\hline 2014 & SDI & 84.7 & 0.45 & $\mathrm{~N} 1$ & 87.2 & 0.48 \\
& DI & 77.9 & 0.44 & $\mathrm{~N} 2$ & 86.5 & 0.51 \\
& & & & $\mathrm{~N} 3$ & 94.8 & 0.47 \\
\hline 2015 & SDI & 90.0 & 0.40 & $\mathrm{~N} 1$ & 101.7 & 0.43 \\
& DI & 93.0 & 0.37 & $\mathrm{~N} 2$ & 99.3 & 0.44 \\
& & & & $\mathrm{~N} 3$ & 100.9 & 0.42 \\
\hline
\end{tabular}

658

659 
660 Table 8. Residual weed biomass and the relationship between weeds and solar noon 661 temperatures measured on August 28, 2013 after herbicide burn-down.

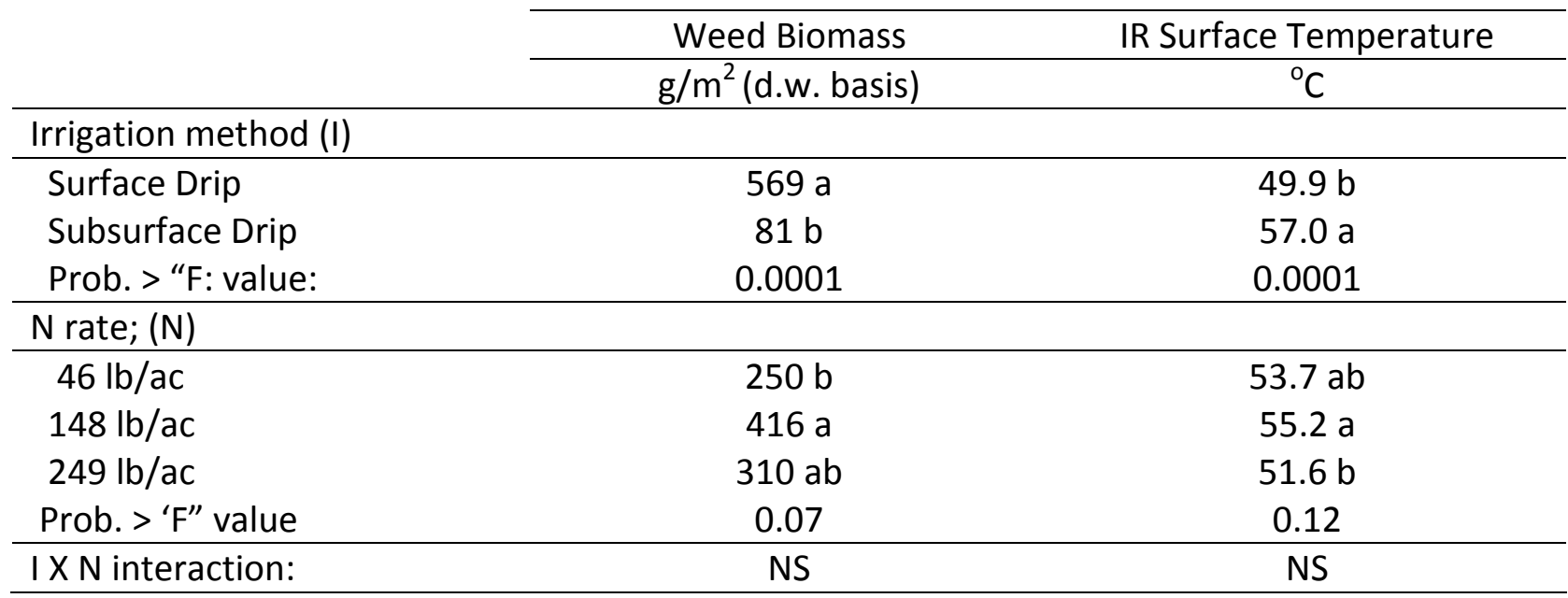

662

663

664

665

666

667 


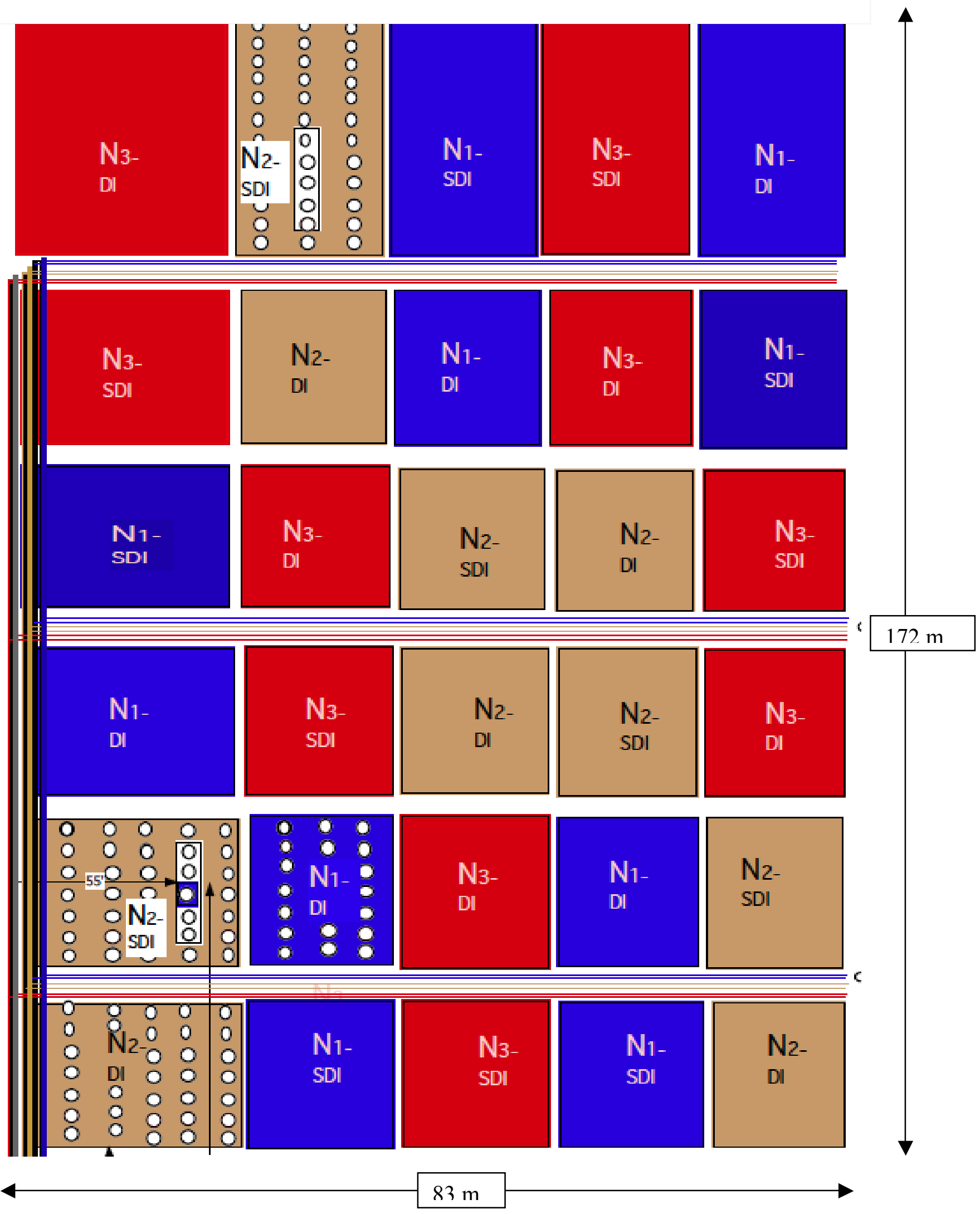




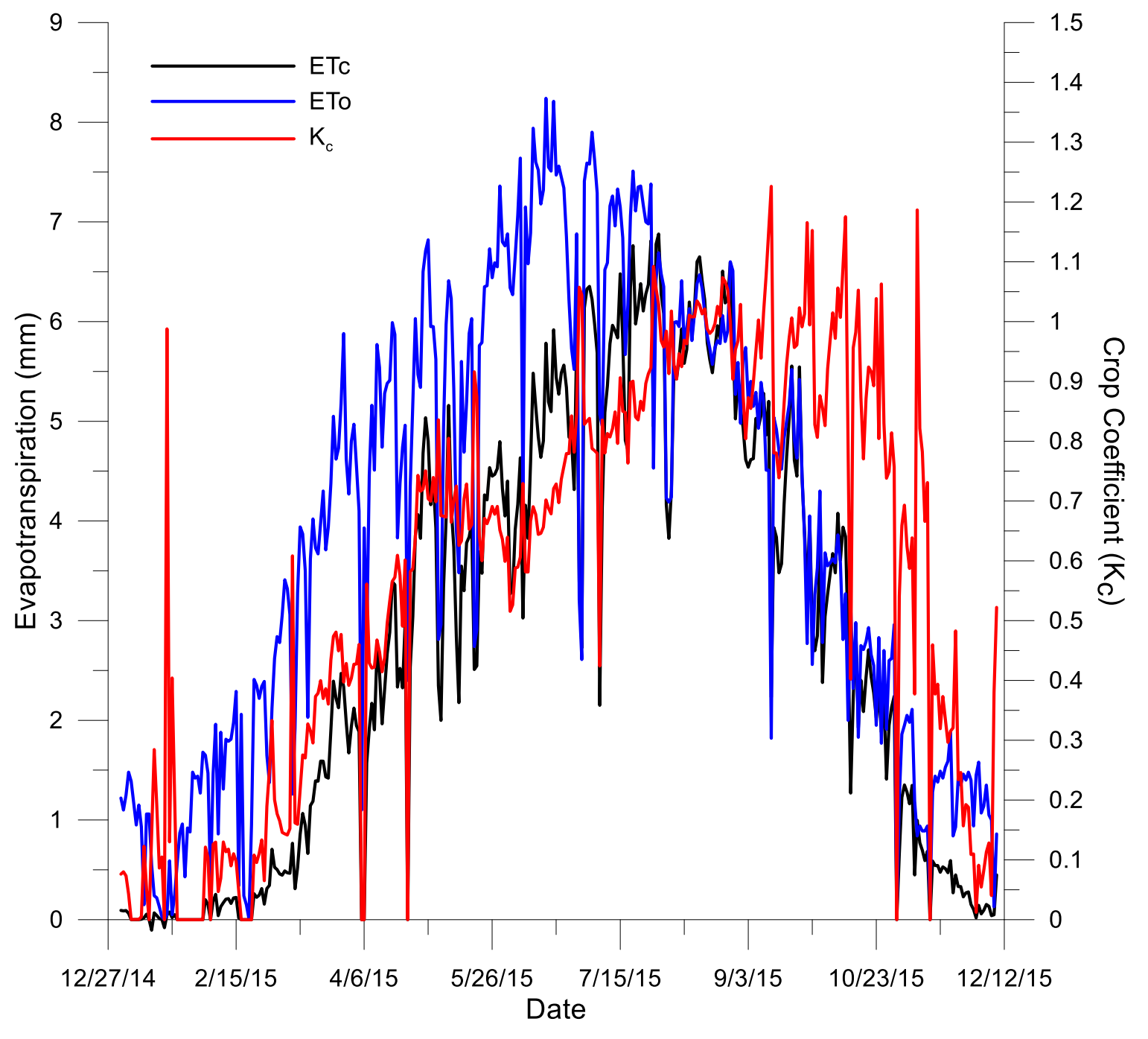


Date
3/26/2013 5/15/2013 $7 / 4 / 2013 \quad 8 / 23 / 2013 \quad 10 / 12 / 2013$ 12/1/2013 $1 / 20 / 2014$
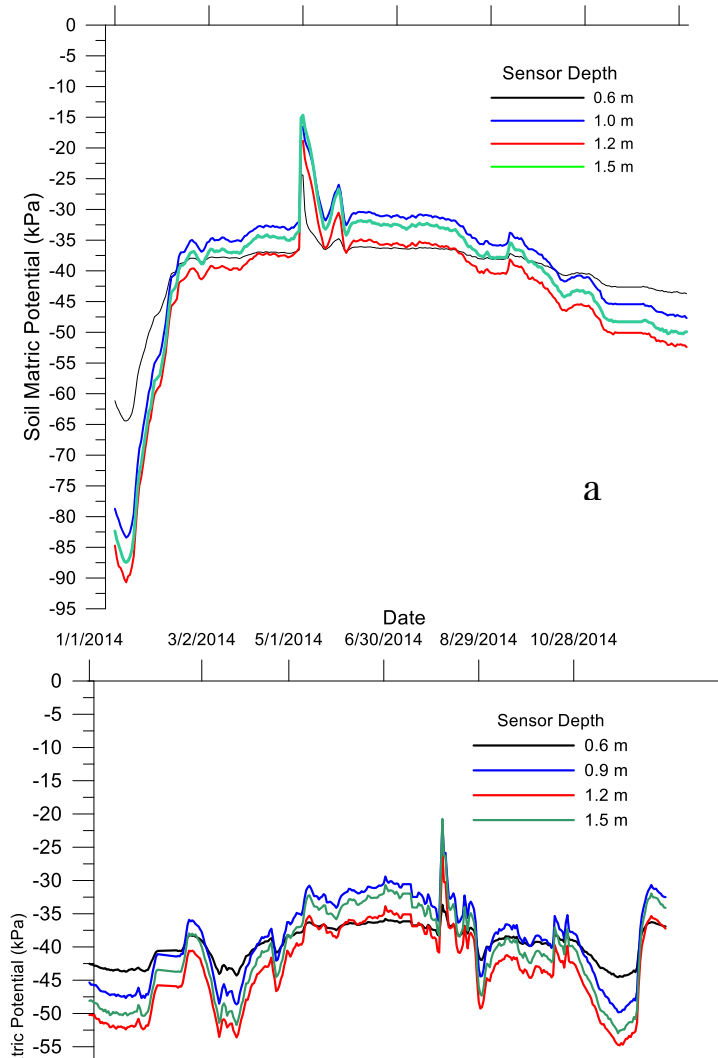

$\sum^{\frac{5}{2}}-65$

$-65$

$-70$

$-80$

$-85$

$-90-$

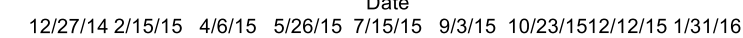

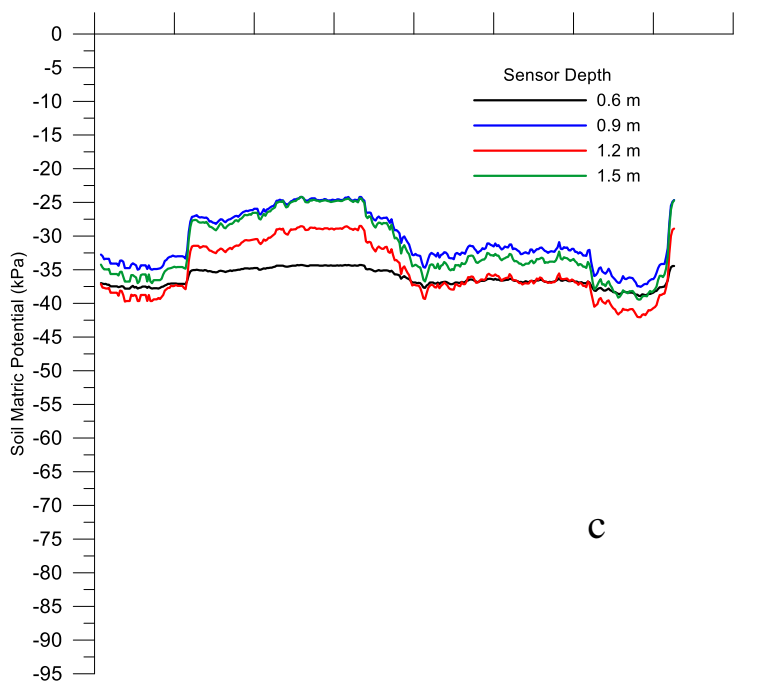



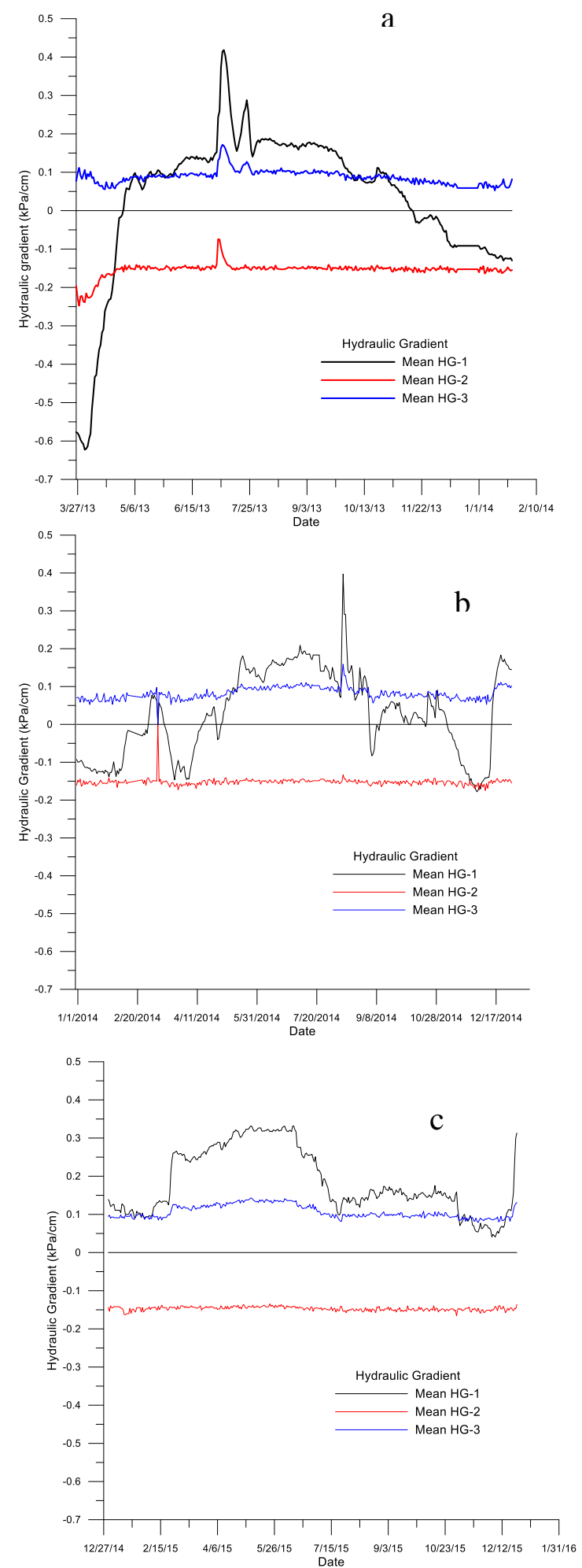

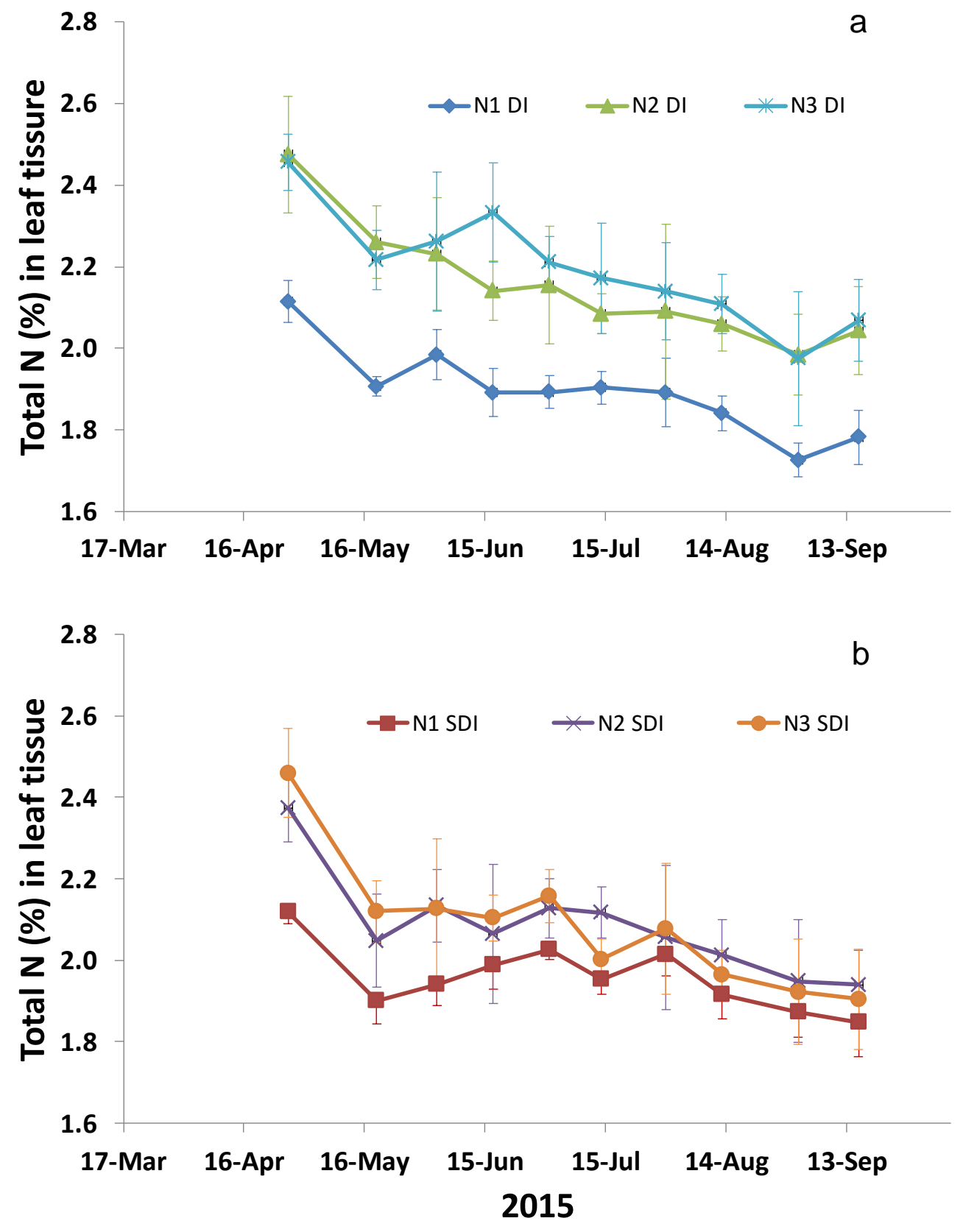

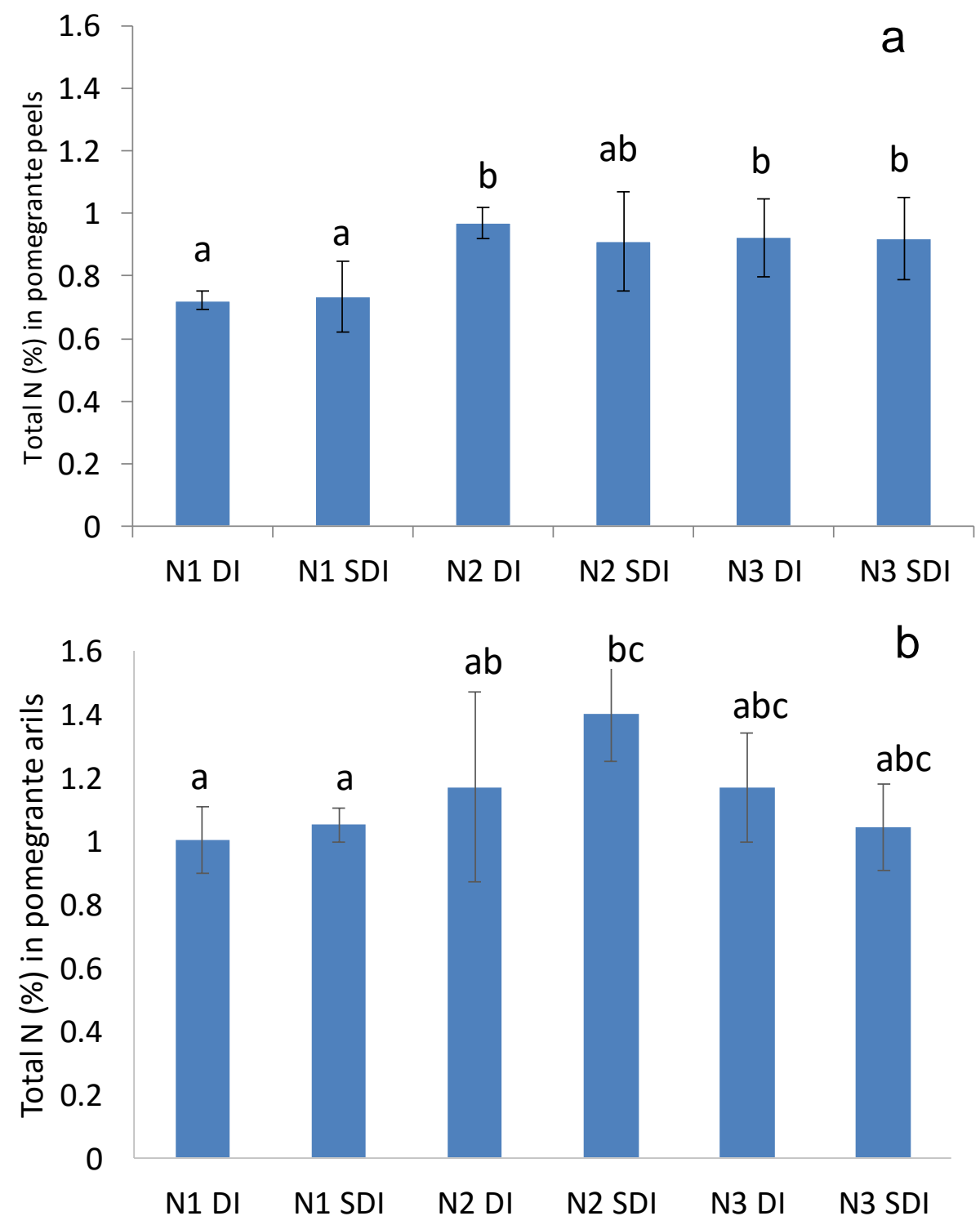


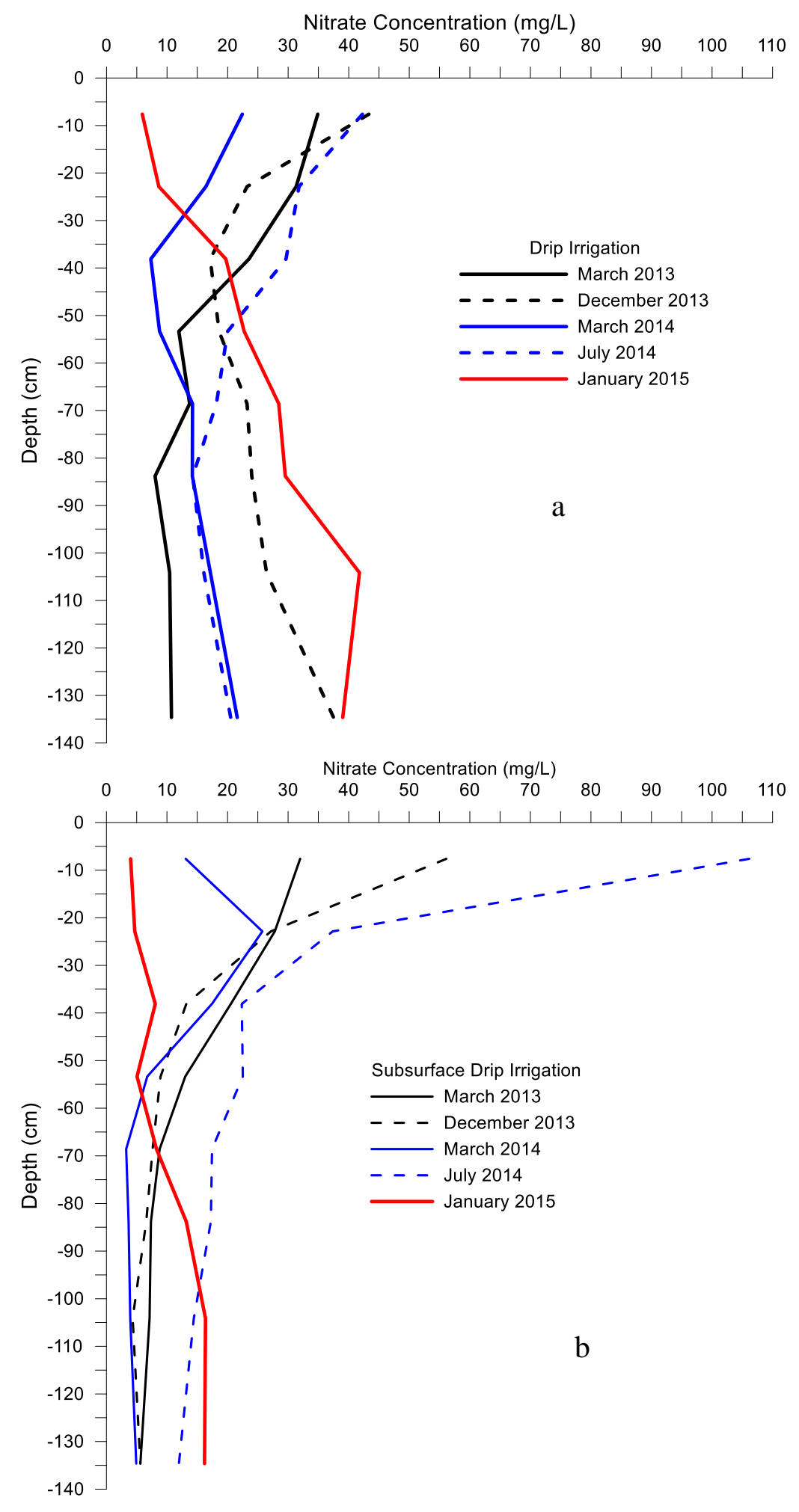




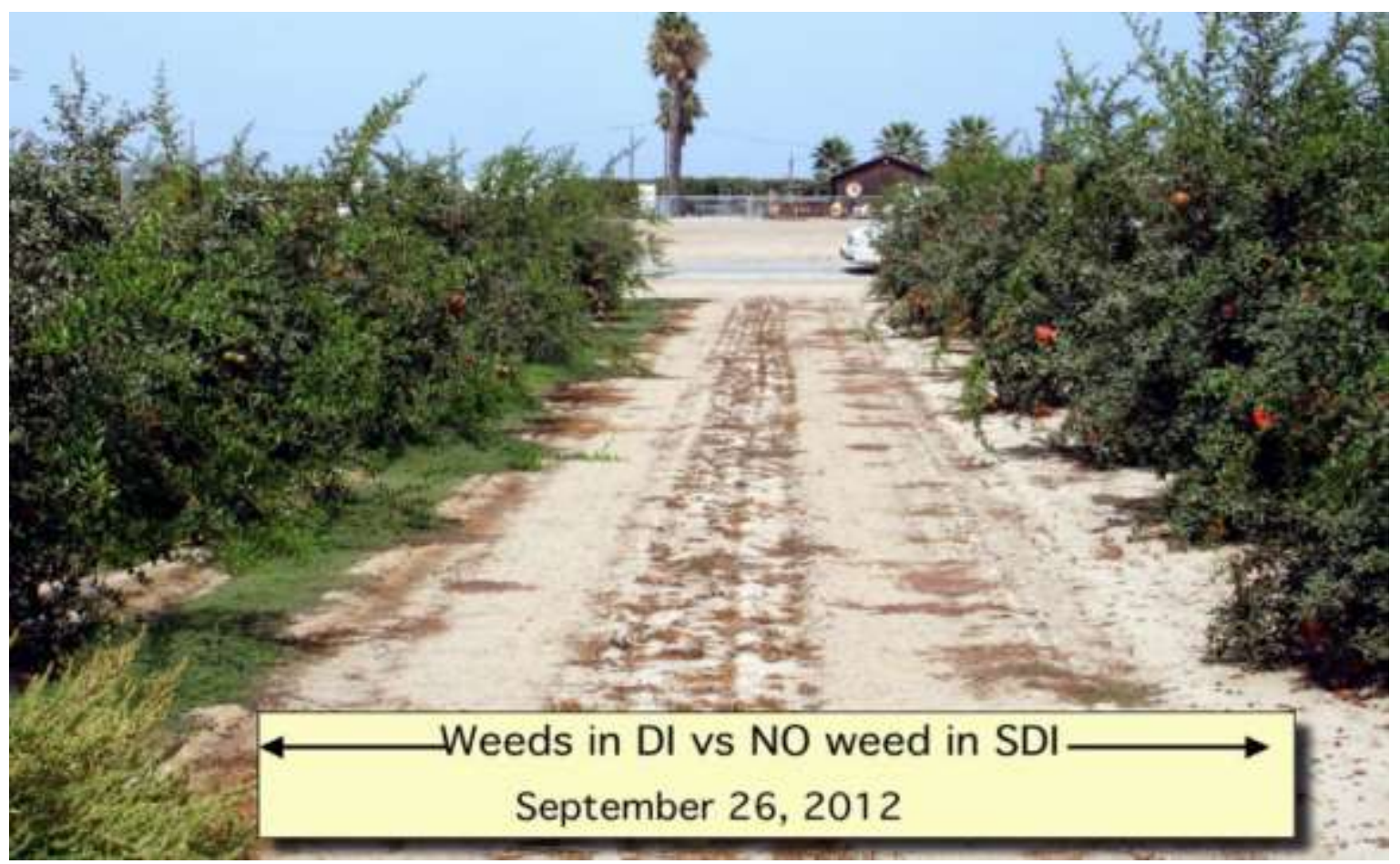

